\title{
Analysis of Air Temperature Distribution in a Closed House for Broiler in Wet Tropical Climate
}

\author{
A. Yani ${ }^{\mathrm{a}, *}$, , H. Suhardiyanto ${ }^{\mathrm{b}, \sharp}$, Erizal $^{\mathrm{c}, \sharp}$, \& B. P. Purwanto ${ }^{\mathrm{d}}$ \\ aStudy Program of Agricultural Engineering, Graduate School, Bogor Agricultural University \\ Gedung Andi Hakim Nasoetion, Kampus IPB Darmaga Bogor 16680, Indonesia \\ bDepartment of Mechanical and Biosystem Engineering, Faculty of Agricultural Engineering, \\ Bogor Agricultural University \\ 'Department of Civil and Environmental Engineering, Faculty of Agricultural Engineering, \\ Bogor Agricultural University \\ \#Kampus IPB Darmaga, Bogor 16002, Indonesia \\ ${ }^{\mathrm{d} D i r e c t o r a t e}$ of Diploma Program, Bogor Agricultural University \\ Jln. Kumbang No. 14, Kampus IPB Cilibende Bogor 16151, Indonesia \\ (Received 09-05-2014; Reviewed 02-06-2014; Accepted 16-06-2014)
}

\begin{abstract}
The objective of this research was to analyze the air temperature distribution in a closed house system for broiler in wet tropical climate by using computational fluid dynamics (CFD) to figure out the comfort level of the broiler in that system. The dimension of the experimental house was $\mathbf{1 0 0}$ $\mathrm{m} \times 10 \mathrm{~m} \times 2.4 \mathrm{~m}$ which could be occupied by 12,000 to 16,000 broiler chickens. The wall was made from expose mercy brick and curtain, plafond was made from galvanize, ventilation system used 6 fans with $1.27 \mathrm{~m}$ diameter and cooling pad and in-house lighting system used 60 units of 8 Watt lamps. The analysis of temperature distribution using CFD had high precision as was shown by the small number of average percentage of deviation $(6.39 \%)$ between analyzed and measured results. Horizontally, the temperature distribution near the cooling pad was lower than others and continued to increase until near the position of the fan. In vertically, the air temperature in the area near the husks and the plafond were higher than the other mesurement points. At that height, the effective temperatures which were still comfort for the broiler were $20.07^{\circ} \mathrm{C}, 19.81^{\circ} \mathrm{C}$ and $20.04{ }^{\circ} \mathrm{C}$ at $12: 20 \mathrm{~h}$, 13:55 $\mathrm{h}$ and 15:20 $\mathrm{h}$, respectively.
\end{abstract}

Key words: air temperature distribution, closed house, broiler, computational fluid dynamics

\section{ABSTRAK}

Penelitian ini bertujuan menganalisis distribusi suhu udara pada kandang ayam broiler sistem tertutup di daerah beriklim tropika basah menggunakan computational fluid dynamics (CFD) untuk menentukan tingkat kenyamanan ayam broiler pada kandang sistem tertutup. Kandang yang digunakan berukuran $100 \mathrm{~m} \times 10 \mathrm{~m}$ x 2,4 m, yang dapat menampung 12.000 sampai 16.000 ekor ayam broiler. Lantai kandang terbuat dari semen beton, dinding terbuat dari bata expose mercy dan tirai, plafon menggunakan galvanis, sistem ventilasi menggunakan 6 kipas berdiameter 1,27 m dan cooling pad dan sistem pencahayaan dalam kandang menggunakan lampu 8 Watt sebanyak 60 unit. Hasil analisis distribusi suhu udara menggunakan CFD memiliki tingkat validasi dan ketelitian cukup tinggi dengan rendahnya nilai persentase deviasi rata-rata $(6,39 \%)$ antara hasil analisis dengan hasil pengukuran. Secara horizontal, distribusi suhu udara dekat cooling pad lebih rendah dan terus mengalami peningkatan sampai mendekati posisi kipas. Secara vertikal, suhu udara di daerah dekat sekam dan plafon lebih tinggi dibandingkan ketinggian lainnya. Suhu efektif pada ketinggian $0,2 \mathrm{~m}$ sebesar $20,07{ }^{\circ} \mathrm{C}$ (pukul 12.20 WIB), 19,81 ${ }^{\circ} \mathrm{C}$ (pukul $13.55 \mathrm{WIB}$ ) dan $20,04{ }^{\circ} \mathrm{C}$ (pukul 15.20 WIB) yang masih tergolong suhu nyaman untuk ayam broiler.

Kata kunci: distribusi suhu udara, kandang tertutup, broiler, computational fluid dynamics

${ }^{*}$ Corresponding author:

E-mail: a_yanicirebon@yahoo.co.id 


\section{INTRODUCTION}

It is generally accepted that broiler at above 2 weeks of age will grow optimally at temperature's range of 20 to $24{ }^{\circ} \mathrm{C}$ (Herawati \& Adiwinarto, 2012). However, high air temperature and relative humidity condition in Indonesia can potentially cause heat stress for broiler, so the feed efficiency and growth rate of the chicken will decrease (Donald, 2010). Therefore, controlling of thermal factors for broiler production in wet tropical climate is very important.

In Indonesia, a closed housing system is recently used for broiler production. The air temperature and relative humidity of this housing can be controlled by mechanical ventilation and wind tunnel which are equipped with a cooling pad. The ventilation system in the closed house can reduce environmental head load produced by the metabolic heat of the broiler chickens, cage material which exposed to solar radiation, the heat from brooder and heat of litter fermentation (Yahav et al., 2004). Therefore, a good ventilation system is needed to remove heat, moisture and gases (e.g. $\mathrm{CO}, \mathrm{CO}_{2}$, and $\mathrm{NH}_{3}$ ) in the closed housed (Donald, 2010).

One factor that lead in reducing productivity of broiler in the closed house system is air flow rate which does not distribute uniformly around the housing. The non-uniform distribution of air flows in the housing system resulted in uneven distribution of air temperature and relative humidity among places in the housing. This condition can reduce animal performance and increased animal mortality. The problem of air flow distribution in the housing can be analyzed quickly and simultaneously by using computational fluid dynamics (CFD) (Versteeg \& Malalasekera, 1995). Therefore, many studies on the air flow and air temperature distribution of closed house have been done in the cold and temperate regions by using CFD (Vidal et al., 2008; Seoa et al., 2009).

The broiler production in wet tropical climate has trend to use closed house system too, but potential heat stress still exist. This condition is important to be investigated since there is a lack of information on air flow and air temperature distribution in the closed house system in wet tropical climate region. Therefore, a study on the air flow and air temperature distribution of closed house, especially in wet tropical climate, is needed. This present study was done by using CFD to analyze the distribution of air temperature in broiler closed house in wet tropical climate to figure out the comfort level for the chickens in the housing system.

\section{MATERIALS AND METHODS}

The research was carried out in a broiler closed house facility of the Faculty of Animal Science, Bogor Agricultural University, Indonesia and that was started from May to July 2013. The dimension of the experimental design (closed house designed for broiler) was $100 \mathrm{~m} \times 10 \mathrm{~m} \times 2.4 \mathrm{~m}$ (length $\times$ width $\times$ height) which can be occupied by 12,000 up to 16,000 heads of broiler. The floor was made from concrete cement, the roof was asbestos, the stud used iron material, the wall was made from expose mercy brick and curtain, and the plafond used galvanize. The ventilation system used 6 fans with $1.27 \mathrm{~m}$ diameter, 70 sets of cooling pad were set up to decrease the in-house temperature and in-house lighting used 60 units of 6 watt lamp.

The tools used in the experiment were: weather station (Davis 6162), portable paperless recorder (Yokogawa, MV Advance 1000), anemometer, note book and personal computer (PC) with SolidWorks Flow Simulation software. The measured micro environment parameters were the temperatures of plafond, rice husk (litter), curtain, cooling pad and around the fan. The in-house temperature was also measured at three height sections i.e. $0.2 \mathrm{~m}, 0.6 \mathrm{~m}$ and $2.0 \mathrm{~m}$. Thus, three portable paperless recorders with 24 channels and T-thermocouple model were used to measure and record the temperature at specific sections mentioned previously. The measurement was designed as follows: 2 units at each right and left curtain, 3 units at litter, 3 units at plafond, 1 unit at the $0.2 \mathrm{~m}$ depth soil, 4 units at cooling pad, 27 units inside the broiler house set at $0.2 \mathrm{~m}, 0.6 \mathrm{~m}$ and $2.0 \mathrm{~m}$ on y-axis. At each section, the thermocouple was set horizontally (z-axis coordinate) at a distance of $4 \mathrm{~m}, 2.5 \mathrm{~m}$ and $0 \mathrm{~m}$ from the center of the broiler house. The thermocouple was also set on the length side ( $\mathrm{x}$-axis coordinate) at $55 \mathrm{~m}, 20 \mathrm{~m}$ and $-15 \mathrm{~m}$. The positions of measurement points in a closed house for broiler are presented in Figure 1.

The origin coordinate $(0,0,0)$ representing $x, y$ and $\mathrm{z}$ axis which refer to the length, height and width of the broiler house was placed $65 \mathrm{~m}$ length from the right side or $35 \mathrm{~m}$ from the left side $(\mathrm{x})$ above the rice husk space and $5 \mathrm{~m}$ width both from right or left side (z). Figure 2 shows the geometry and the origin coordinate of the experimental house. The thermocouple was coupled with recorder device to display the measured temperature from $06: 00 \mathrm{~h}$ up to 18:00 $\mathrm{h}$ which recorded in every 5 minutes during one breeding period (35 days).

\section{Computational Fluid Dynamic (CFD)}

CFD SolidWorks Flow Simulation is the latest software to compute the air circulation in a broiler closed house system apart from software Fluent 6.2.16, Gambit 2.2.30 and Auto CAD 2005. This software is equipped with complete features such as drawing the geometry of the house, making the mesh, defining the geometry boundary condition, and analyzing the temperature distribution and flow pattern. This software was run using computer with Intel ${ }^{\circledR}$ Core ${ }^{\mathrm{TM}}$ i7, 12 GB RAM CPU and 64 bit operation system.

In CFD (Versteeg \& Malalasekera, 1995), the air circulation pattern was quantitatively described into temperature and velocity through differential equation in the form of cartesian coordinate. Mathematical computation employed in CFD was run through three dimensional numeric analysis with finite volume method by discretization and iteration. The analysis of temperature distribution and simulation was carried out through several processes as follow: defining 3D model, energy consumption, viscous model, material type and thermo physical properties of the fluid, boundary condition input value, initialization, iteration and visualization. 


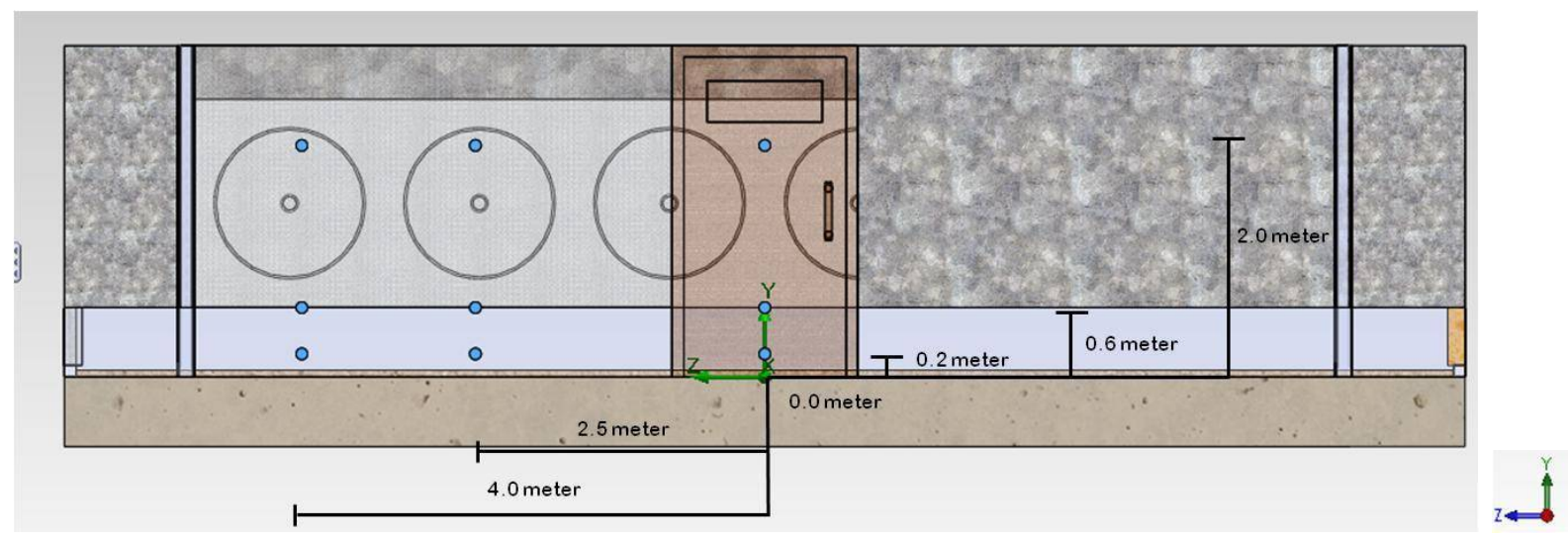

Figure 1. The position of measurent point in a closed house for broiler

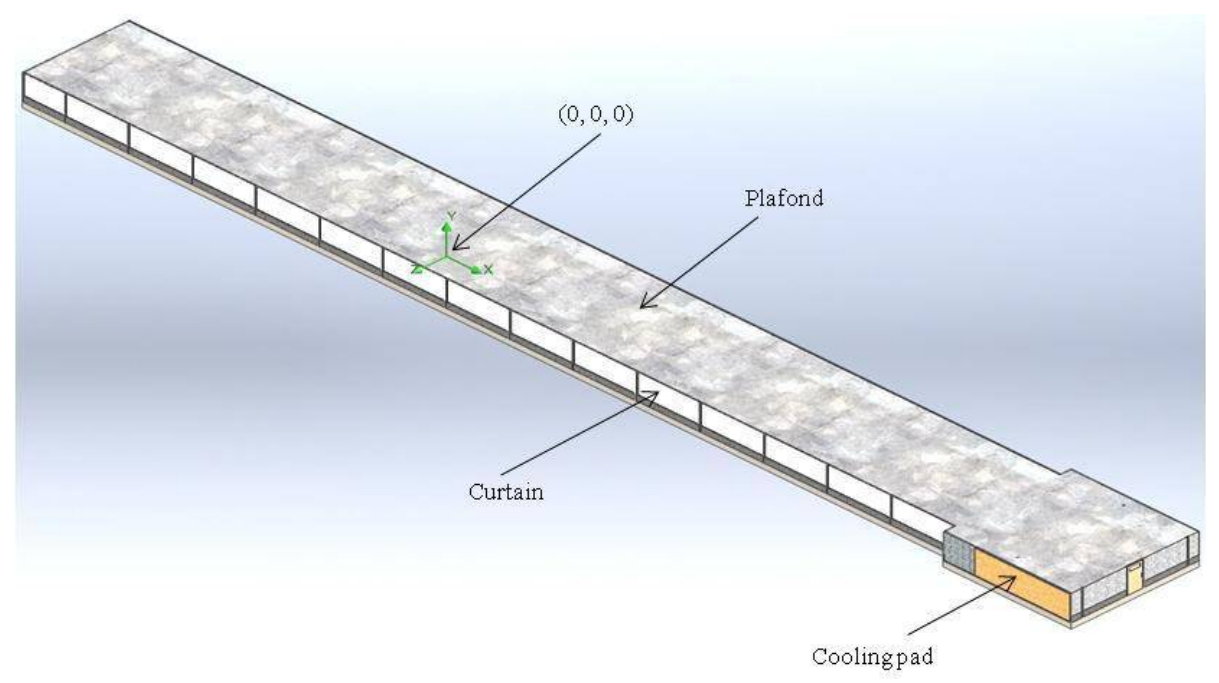

Figure 2. The geometry of the experimental house

CFD consists of 3 main elements i.e.: pre-processor, solver and post-processor (Versteeg \& Malalasekera, 1995). Pre-processor component is an input component of a flow problem in a CFD program by means of interface used to transform input for the solver. In solver computation, there are three streams of fluid: the conservation law of mass, which is the rate of momentum change is equal to the resultant of the forces on a fluid particle (Newton's second law), the rate of change of energy is equal to the resultant of the rate of heat addition to and the rate of work done on a fluid particle (the First Law of Thermodynamic).

The flow of air inside a broiler closed house system has characteristic as turbulent fluid thus standard $\mathrm{k}-\varepsilon$ turbulence model that developed by Lam \& Bremhost (1981) was choosen for calculation in CFD simulation. The computation in solver of CFD based on mass, momentum and energy conservation laws (Versteeg \& Malalasekera, 1995). These equations are described as equation 1 to 3 (Lee et al., 2007).

$\frac{\partial \rho}{\partial t}+\frac{\partial}{\partial x_{i}}\left(\rho u_{i}\right)=S_{m}$ where $x_{i}=$ component of length $(m), u_{i}=$ component of velocity $\left(\mathrm{m} \mathrm{s}^{-1}\right), \rho=$ fluid density $\left(\mathrm{kg} \mathrm{m}^{-3}\right)$ and $S_{m}=$ mass source $\left(\mathrm{kg} \mathrm{m}^{-3} \mathrm{~s}^{-1}\right)$.

$\frac{\partial}{\partial t}\left(\rho u_{i}\right)+\frac{\partial}{\partial x_{i}}\left(\rho u_{i} u_{i}\right)=-\frac{\partial p}{\partial x_{i}}+\frac{\partial \tau_{i j}}{\partial x_{j}}+\rho g_{i}+F_{i}$

where $\mathrm{p}=$ pressure $(\mathrm{Pa}), \tau_{\mathrm{ij}}=$ stress tensor $(\mathrm{Pa})$, $\mathrm{g}_{\mathrm{i}}=$ gravitational acceleration $\left(\mathrm{m} \mathrm{s}^{-2}\right), \mathrm{F}_{\mathrm{i}}=$ external force vector $\left(\mathrm{N} \mathrm{m}^{-3}\right)$, and $\mathrm{t}=$ time $(\mathrm{s})$.

$\frac{\partial}{\partial t}(\rho h)+\frac{\partial}{\partial x_{i}}\left(\rho u_{i} h\right)=\frac{\partial}{\partial x_{i}}\left(K \frac{\partial T}{\partial x_{i}}\right)-\frac{\partial}{\partial x_{i}} \sum_{j} h_{j} J_{j}+\frac{\partial p}{\partial t}+u_{i} \frac{\partial p}{\partial x_{i}}+\tau_{i j} \frac{\partial u_{i}}{\partial x_{j}}+S_{h}(3)$ where $\mathrm{J}_{\mathrm{i}}=$ compenent of diffusion flux $\left(\mathrm{kg} \mathrm{m}^{-2} \mathrm{~s}^{-1}\right), \mathrm{h}=$ specifik enthalpy $\left(\mathrm{J} \mathrm{kg}^{-1}\right), \mathrm{K}=$ thermal conductivity $(\mathrm{W} \mathrm{m}$ $\left.{ }^{1} \mathrm{~K}^{-1}\right)$, Sh= total entropy $\left(\mathrm{J}^{\circ} \mathrm{K}^{-1}\right)$ and $\mathrm{T}=$ temperature $\left({ }^{\circ} \mathrm{K}\right)$.

The result of pre-processor and solver was then displayed in post-processor in the form of domain geometry and grid display, vector plot, two or three dimensional surface plots, air temperature and flow rate, particle movement and color output.

The underlying assumptions used in the analysis of air temperature distribution in closed house broiler 
using CFD were: 1) the in-house air was considered as incompressible fluid, 2) the rotary motion of fan was constant during simulation, 3) the specific heat, conductivity and viscosity of air were constant.

\section{Model Validation}

Validation was carried out through comparing the result obtained from the measurement with the results obtained by computation resulted at each determined sections. The validation criteria at each height sections of $0.2,0.6$ and $2.0 \mathrm{~m}$ was analyzed by means of average percentage of deviation of the measurement and simulation result. The average percentage of deviation was computed by equation (4).

Average percentage of deviation $=\left(\frac{T_{\text {simulation }}-T_{\text {measured }}}{T_{\text {measured }}}\right) \times 100 \%$

\section{RESULTS AND DISCUSSION}

The analysis of air temperature distribution in the experimental house was conducted when the house was filled with rice husk and no broiler inside. The experiment was carried out in 29 June 2013 representing fine weather in dry season considering that the experimental house was affected by micro environment condition outside of the house such as: temperature, relative humidity and radiation (Yani \& Purwanto, 2006; Yani et al., 2007). Timing for the analysis of the temperature distribution in the closed house of broiler was selected becaused at that time based on the condition of the cooling pad flame on for both of the right and left sides, with a temperature difference between right and left side of cooling pad was relatively low. It was occurred at 12:20 h, 13:55 $\mathrm{h}$ and 15:20 h.

The radiation intensities at $12: 20 \mathrm{~h}, 13: 55 \mathrm{~h}$ and 15:20 h were $775 \mathrm{Watt} / \mathrm{m}^{2}, 650 \mathrm{Watt} / \mathrm{m}^{2}$ and $380 \mathrm{Watt} / \mathrm{m}^{2}$, respectively. The outside temperatures and relative humidities at those respective times were $33.40{ }^{\circ} \mathrm{C}, 33.8^{\circ} \mathrm{C}$ and $34.60{ }^{\circ} \mathrm{C} ; 60 \%, 59 \%$ and $56 \%$, respectively. The temperatures of the roof and the $0.2 \mathrm{~m}$ depth soil at 12:20 $\mathrm{h}$, $13: 55 \mathrm{~h}$ and $15: 20 \mathrm{~h}$ were $51.69^{\circ} \mathrm{C}, 46.17^{\circ} \mathrm{C}, 43.12^{\circ} \mathrm{C}$; and $32.64{ }^{\circ} \mathrm{C}, 32.45^{\circ} \mathrm{C}, 32.43{ }^{\circ} \mathrm{C}$.

Curtain, plafond and rice husk in CFD computation for boundary condition was defined as real wall. Temperatures of curtain and cooling pad at right and left side were different because of solar incline. Solar incline at left side was greater than at right side. Air that flowed to inside broiler closed house system through cooling pad was defined as wet air containing $\mathrm{RH}$ between $95 \%$ and $97 \%$ thus the temperature of cooling pad was different than the temperature of water at pencirculation cooling pad. These temperatures were results of measurement. Inputs of initial condition and boundary condition for computation of analysis of air distribution in closed house system for broiler using CFD are described at Table 1.

Table 1. Initial and boundary input condition for air temperature distribution analysis in the experimental house

\begin{tabular}{lccc}
\hline \multirow{2}{*}{ Input } & \multicolumn{3}{c}{ Time } \\
\cline { 2 - 4 } & $12: 20 \mathrm{~h}$ & $13: 55 \mathrm{~h}$ & $15: 20 \mathrm{~h}$ \\
\hline Initial condition & & & \\
Ricehusk/litter temperature $\left({ }^{\circ} \mathrm{C}\right)$ & 31.35 & 31.32 & 31.25 \\
Plafond temperature $\left({ }^{\circ} \mathrm{C}\right)$ & 33.72 & 32.90 & 32.60 \\
Right curtain temperature $\left({ }^{\circ} \mathrm{C}\right)$ & 33.79 & 33.18 & 33300 \\
Left curtain temperature $\left({ }^{\circ} \mathrm{C}\right)$ & 35.54 & 35.84 & 35.71 \\
Right cooling pad temperature & 26.16 & 26.26 & 26.11 \\
$\left({ }^{\circ} \mathrm{C}\right)$ & 26.27 & 26.42 & 26.07 \\
Left cooling pad temperature $\left({ }^{\circ} \mathrm{C}\right)$ & 9.83 & 9.83 & 9.83 \\
Gravitational acceleration $\left(\mathrm{m} / \mathrm{s}^{2}\right)$ & & & \\
Boundary condition & 1028 & 1026 & 1026 \\
Atmospheric pressure $($ Bar $)$ & 5 & 5 & 5 \\
No of activated exhaust fan & 0.00 & 0.00 & 0.00 \\
Static pressure of fan & 11.67 & 11.67 & 11.67 \\
Air rate each fan (m $3 / \mathrm{s})$ & $3($ default) & $3($ default) & 3 (default) \\
Meshing & \multicolumn{3}{c}{} \\
\hline
\end{tabular}

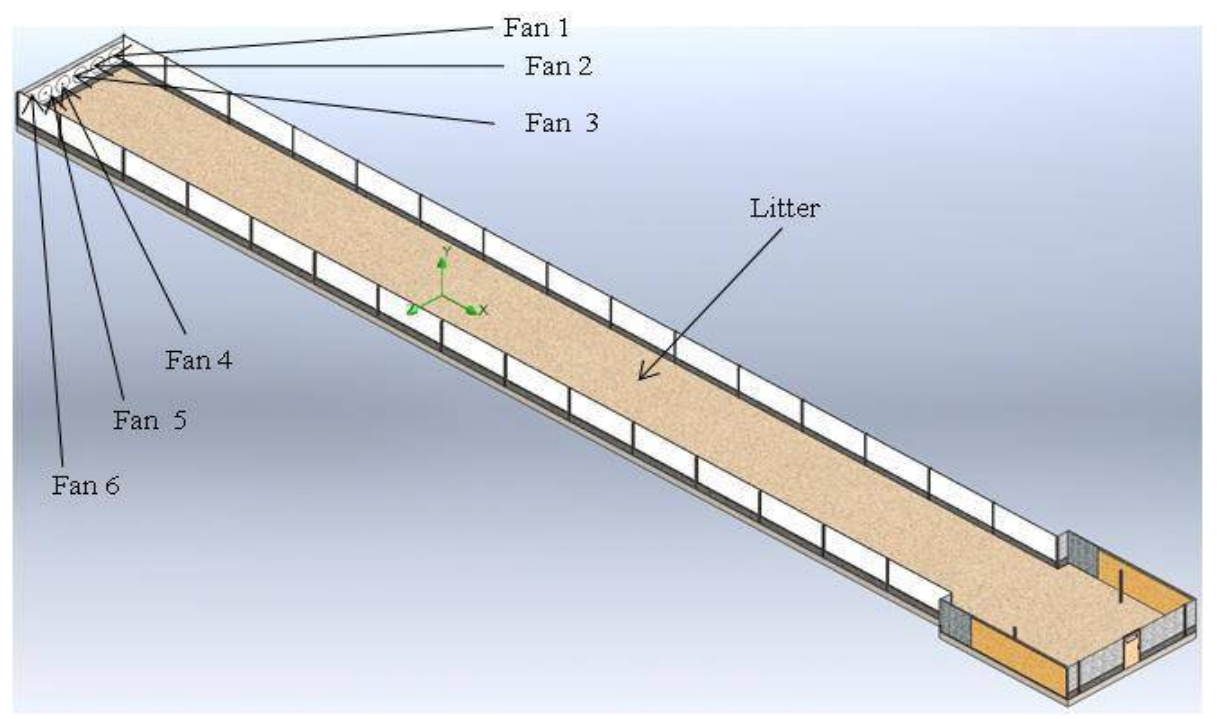

Figure 3. The position of fan set up in the experimental house 
Table 2. The air temperature of the experimental house resulted from CFD

\begin{tabular}{clccc}
\hline \multirow{2}{*}{$\begin{array}{c}\text { Height }(\mathrm{m}) \\
0.2\end{array}$} & Value & \multicolumn{3}{c}{ Air temperature $\left({ }^{\circ} \mathrm{C}\right)$} \\
\cline { 2 - 4 } & Minimum & $26.16 \mathrm{~h}$ & $13: 55 \mathrm{~h}$ & $15: 20 \mathrm{~h}$ \\
\hline & Maximum & 28.99 & 28.26 & 26.07 \\
& Average & 27.61 & 27.59 & 28.59 \\
& Coefficient of & 3.08 & 3.04 & 2.99 \\
& variance $(\%)$ & & & \\
0.4 & Minimum & 26.16 & 26.26 & 26.07 \\
& Maximum & 28.26 & 28.23 & 28.17 \\
& Average & 26.96 & 26.95 & 27.10 \\
& Coefficient of & 2.13 & 2.12 & 2.45 \\
& variance $(\%)$ & & & \\
0.6 & Minimum & 26.16 & 26.26 & 26.07 \\
& Maximum & 28.56 & 28.71 & 28.19 \\
& Average & 26.68 & 26.66 & 26.70 \\
& Coefficient of & 26.16 & 1.66 & 2.32 \\
& variance $(\%)$ & & & \\
2.0 & Minimum & 26.16 & 26.26 & 26.07 \\
& Maximum & 28.69 & 28.59 & 28.72 \\
& Average & 26.88 & 26.77 & 26.91 \\
& Coefficient of & 2.53 & 2.36 & 2.78 \\
& variance $(\%)$ & & & \\
\hline
\end{tabular}

The air flow capacity entering the house through air inlet of cooling pad was strongly influenced by the number of fans running (Figure 3). The numbers of fans ran at 12:20 h, 13:55 $\mathrm{h}$ and 16:00 $\mathrm{h}$ were 5 units (the $2^{\text {nd }}$ fan were turned off). The diameter of fan was $1.27 \mathrm{~m}$ and the air flow capacity was $11.66 \mathrm{~m}^{3} / \mathrm{s}$. As a result, the air flow capacities of fans were $58.29 \mathrm{~m}^{3} / \mathrm{s}$ at 12:20 h, 13:55 $\mathrm{h}$ and 16:00 $\mathrm{h}$. The temperature of air entering the house was lower than the surrounding temperature which then expected to decrease the temperature inside the experimental house.

According to the boundary condition and micro environment around the experimental house, the temperature distribution resulted from CFD simulation showed that the air temperature near the rice husk and the plafond tended to be higher than other measurement points. It becaused of the air temperature near the rice husk and the plafond while cooling pad is located at 0.4 $\mathrm{m}$ to $2.2 \mathrm{~m}$ of high. Plafond had higher temperature due to the heat released from the roof and the lamp attached on plafond. The lowest average temperature at each height sections occurred at 13:55 h $\left(26.66^{\circ} \mathrm{C}\right)$ compared to at $12: 20 \mathrm{~h}\left(26.68^{\circ} \mathrm{C}\right)$ and at $15: 20 \mathrm{~h}\left(26.70{ }^{\circ} \mathrm{C}\right)$.

The CFD analysis resulted uniform temperature distribution inside the experimental house which was defined by the small value of coefficient of variance i.e. $2.42 \%$ at $12: 20 \mathrm{~h}, 2.37 \%$ at $13: 55 \mathrm{~h}$ and $2.62 \%$ at $15: 20 \mathrm{~h}$. At $12: 20 \mathrm{~h}$, as 5 fans were applied and the temperatures of cooling pad were $26.16{ }^{\circ} \mathrm{C}$ (right side) and $26.27{ }^{\circ} \mathrm{C}$ (left side), the minimum in-house temperature was $26.16^{\circ} \mathrm{C}$ at every height sections. The maximum of in-house temperature was $28.99{ }^{\circ} \mathrm{C}$ which was found at the height of $0.2 \mathrm{~m}$ (Table 2). At 13:55 h, as 5 fans were applied and the temperatures of cooling pad were $26.26{ }^{\circ} \mathrm{C}$ (right side) and $26.42{ }^{\circ} \mathrm{C}$ (left side) produced the minimum in-house temperature of $26.26^{\circ} \mathrm{C}$ located at every height sections and the maximum of $28.96{ }^{\circ} \mathrm{C}$ located at 0.2 height. At $15: 20 \mathrm{~h}$, as 5 fans were applied and the temperatures of cooling pad were $26.11{ }^{\circ} \mathrm{C}$ (right side) and $26.07{ }^{\circ} \mathrm{C}$ (left side), the minimum in-house temperature was $26.07{ }^{\circ} \mathrm{C}$ located at every height sections and the maximum was $28.72{ }^{\circ} \mathrm{C}$ located at the height of $2.0 \mathrm{~m}$.

The minimum air temperature at the height of 0.2 $\mathrm{m}$ from the rice husk was very beneficial considering the activity of the broiler such as locomotion, resting, eating and drinking. According to the CFD results, the averages temperature at $0.2 \mathrm{~m}$ height at 12:20 h, 13:55 h and $15: 20 \mathrm{~h}$ were $27.61{ }^{\circ} \mathrm{C}, 27.59^{\circ} \mathrm{C}$ and $27.46^{\circ} \mathrm{C}$, respectively. Besides of air temperature surrounding the broiler, the air velocity also influenced the comfort level of the broiler. The values of air velocity at $0.2 \mathrm{~m}$ height at those respective times were $1.58 \mathrm{~m} / \mathrm{s}, 1.69 \mathrm{~m} / \mathrm{s}$ and $1.53 \mathrm{~m} / \mathrm{s}$. Those values revealed that the air velocity in the experimental house were higher than the recommended value i.e. $1.41 \mathrm{~m} / \mathrm{s}$ in order to decrease air temperature inside closed house as high as $5.74{ }^{\circ} \mathrm{C}$ (Dagtekin et al., 2009). Thus, the live weight of broiler could gain daily by 112 $\mathrm{g}$ at 37 to 51 days of age (Dozier et al., 2006) with the increased the feed intake (Donald, 2010). Based on the air temperature and wind speed, the effective temperatures at $0.2 \mathrm{~m}$ of height were $20.07{ }^{\circ} \mathrm{C}, 19.81^{\circ} \mathrm{C}$ and $20.04{ }^{\circ} \mathrm{C}$ at 12:20 h, 13:55 $\mathrm{h}$ and 15:33 h, respectively. Those effective temperatures were still comfort for the broiler without considering the metabolic heat generated by broiler (Donald, 2010; Pereira \& Naas, 2008).

The distribution of air temperature at each height (Figure 4) at 12:20 h showed a uniform pattern. The temperature near the cooling pad was lower than at the other locations because this location was the first area that crossed through by cold air from cooling pad. The cold air pulled by fan from cooling pad located in the corner of the house directly brought the air into the fan. This due to the pressure at the corner of the house that was higher than the pressure near the cooling pad located at the center of the house. This condition caused the cold air coming in through the cooling pad moves steadily towards the fan and cool the enclosure along the $100 \mathrm{~m}$ thus getting closer to the fan, the air temperature was higher than the position near the cooling pad.

At 13:55 $\mathrm{h}$, the distribution of air temperature at each height showed the same pattern (Figure 5) that is getting close to the cooling pad is getting cold and the temperature continued to rise until near the fan (Bokkers et al., 2010). The position of the cooler air temperatures at a height of $0.6 \mathrm{~m}$ (Figure $5 \mathrm{~b}$ ) wider than the height of $0.2 \mathrm{~m}$ (Figure 5a) and a height of $2.0 \mathrm{~m}$ (Figure 5c). This condition illustrates that at the height of $0.2 \mathrm{~m}$ (near the rice husk) and 2.0 (near the plafond) the air temperature is influenced by the temperatures of rice husk and plafond that higher than the cooling pad. Cold air from the cooling pad that goes in to the along closed house has a greater mass so that when distributed to the direction of the fan (outlet), the mass of cold air reduced because it is used to absorb the heat that comes from the released from rice husks, curtains, walls and plafond. At the height of $0.2 \mathrm{~m}$, with a temperature of $31.32{ }^{\circ} \mathrm{C}$ rice husks higher than the temperature of the cooling 
(a)

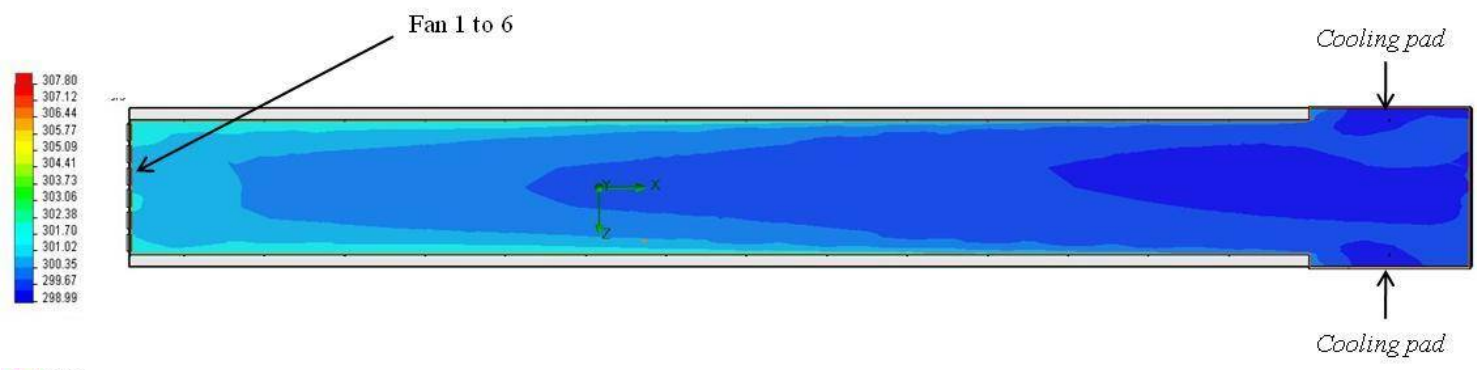

(b)

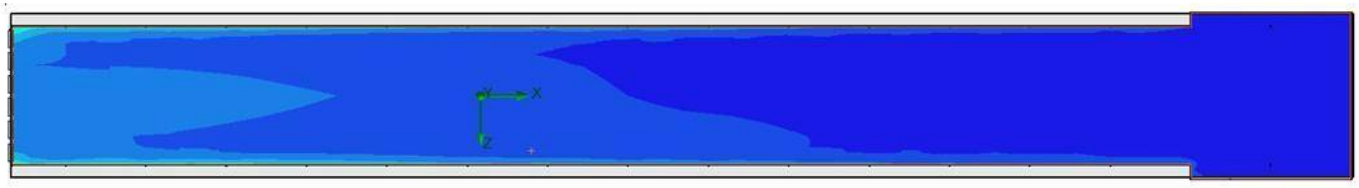

(c)

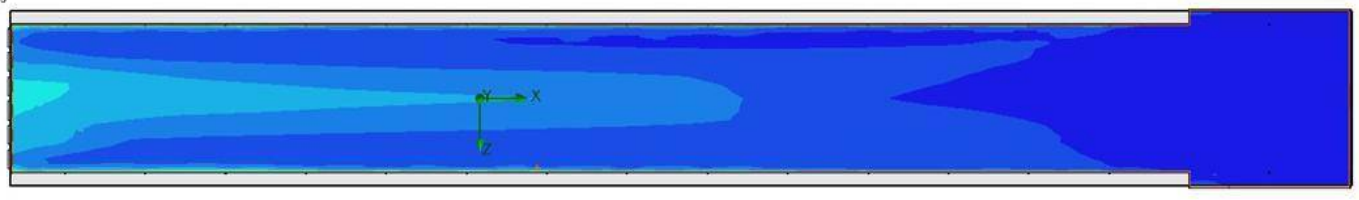

Figure 4. The air temperature distribution in the closed house on 12:20 h (29 June 2013) at $0.2 \mathrm{~m}(\mathrm{a}), 0.6 \mathrm{~m}$ (b) and $2.0 \mathrm{~m}$ (c) height.

(a)

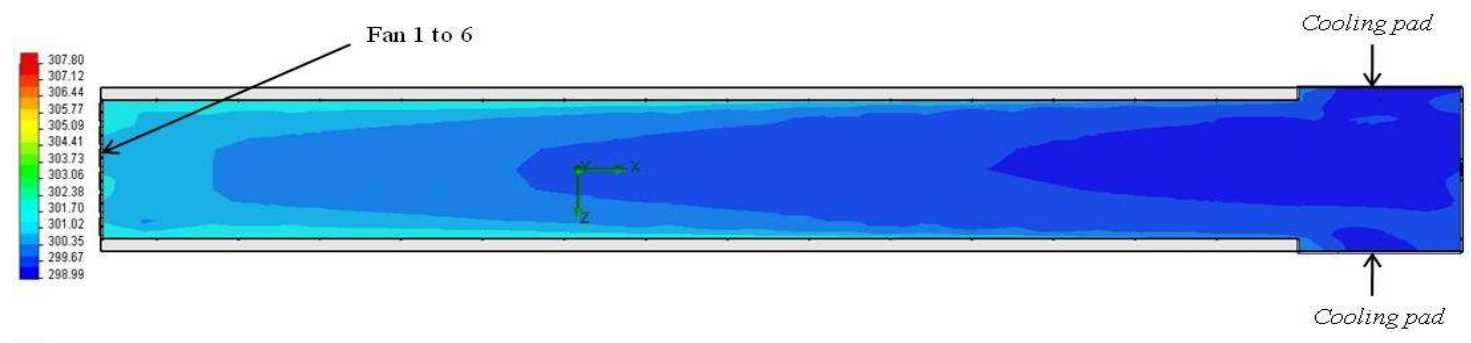

(b)

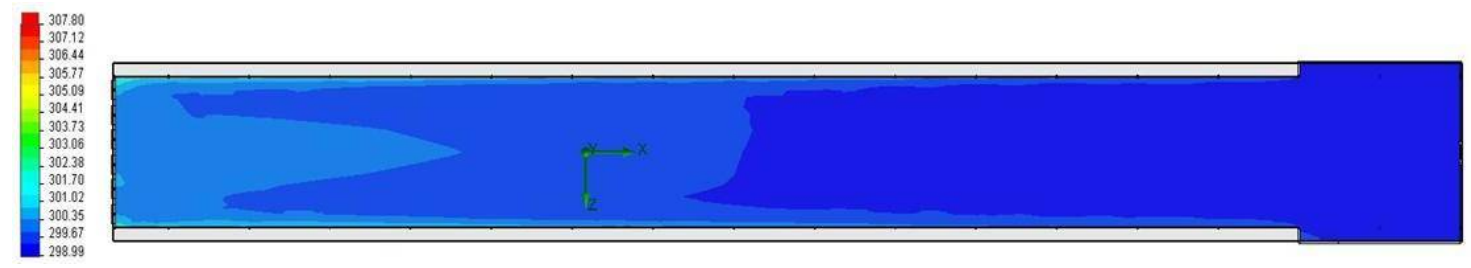

(c)

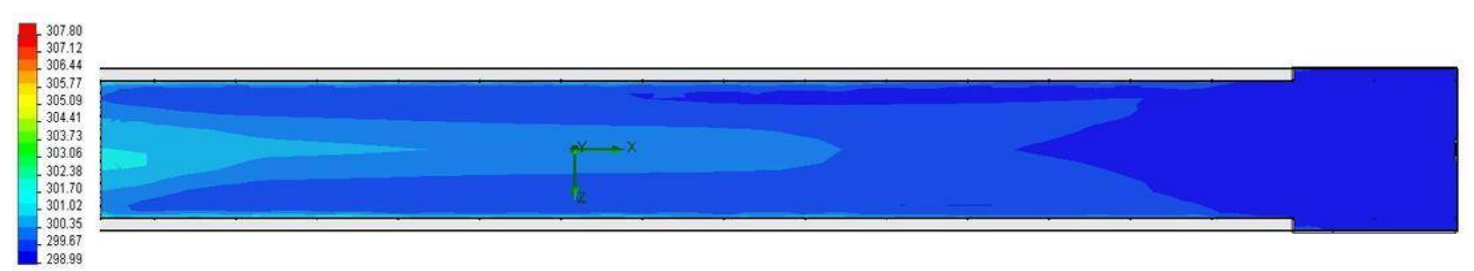

Figure 5. The air temperature distribution in the closed house on 13:55 h (29 June 2013) at $0.2 \mathrm{~m} \mathrm{(a),} 0.6 \mathrm{~m}$ (b) and $2.0 \mathrm{~m}$ (c) height.

pad with a difference of $4.90{ }^{\circ} \mathrm{C}$ (cooling pad left) until $5.06{ }^{\circ} \mathrm{C}$ (cooling pad right) caused the cold air an able to completely absorb the heat from the rice husks and the cold air is more concentrated at the center of closed house. At the height of $2.0 \mathrm{~m}$ (near the ceiling) with a temperature difference of the cooling pad and ceiling of $6.48{ }^{\circ} \mathrm{C}$ temperature (cooling pad left) to $6.64{ }^{\circ} \mathrm{C}$ (cool- ing pad right), hot air from the plafond caused cold air temperature of the cooling pad is not fully able to cool the enclosure temperature, mainly at half the length of the closed house up to ward the fan.

At 15:20 h, the materials of the closed house such as plafond, curtain and rice husks started to release the heat that shown by the increasing of temperature 
(a)

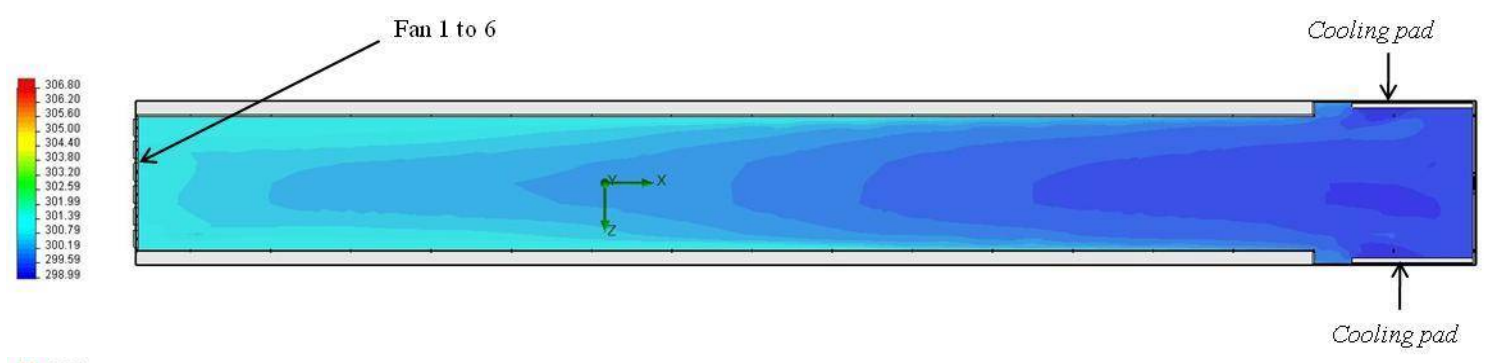

(b)
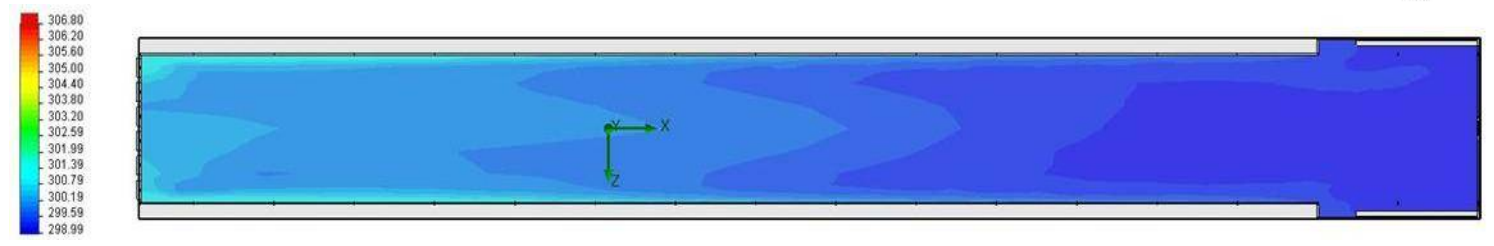

(c)
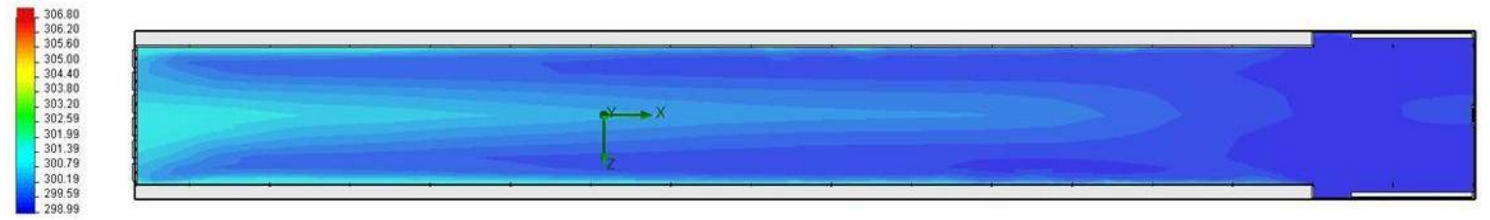

Figure 6. The air temperature distribution in the closed house on 15:20 h (29 June 2013) at $0.2 \mathrm{~m} \mathrm{(a),} 0.6 \mathrm{~m}$ (b)and $2.0 \mathrm{~m}$ (c) height.

at measurement points. This causes the temperature distribution of cold air coming from the cooling pad had lower capability to reduce the air temperature inside closed house compared to at 12:20 h and at $13.55 \mathrm{~h}$, as seen in Figure 3.5a to Figure 6c.

The analysis of air distribution in a closed house for broiler using CFD had small average percentage of deviation $(6.39 \%)$. This demonstrated that the determination of material and boundary condition was sufficiently depicted the real condition of the experimental house. The average percentage of deviation was generated from the validation stage by comparing the result of CFD and the measurement at three different times i.e. 12:20 h, 13:55 $\mathrm{h}$ and 15:20 $\mathrm{h}$ in 27 positions at $0.2 \mathrm{~m}, 0.6 \mathrm{~m}$ and 2.0 $\mathrm{m}$ heights. The average percentage of deviation resulted from validation at 12:20 h, 13:55 $\mathrm{h}$ and 15:20 $\mathrm{h}$ were accordingly $6.25 \%, 6.94 \%$ and $5.99 \%$ higher than the results found by Vidal et al. (2008) i.e. 5 up to $16 \%$. Those small value of average percentage of deviation revealed that the simulation of CFD for analyzing air temperature distribution in a closed house for broiler in wet tropical climate could be used as a tool to design the house density (number of broilers per square area) and to design the structure of the house based on the air temperature distribution perspective. In order to design the density and the structure of the house, input data used for solver were data obtained at 13:00 h (noon) as the peak condition of radiation intensity and environment temperature occured at that time. The temperature inside the closed house broiler in wet tropical climate was influenced profoundly by micro environment surrounding the house.

\section{CONCLUSION}

Computational fluid dynamics (CFD) was suitable for analyzing the air temperature distribution in a closed house for broiler in wet tropical climate which generated high level of validation. The temperature distribution from the rice husk area to the plafond tended to increase. At $0.2 \mathrm{~m}$ height, the effective temperature was still comfortable for the broilers.

\section{REFERENCES}

Bokkers, E. A. M., H. H. E.Van Zanten, \& H. Van den Brand. 2010. Field study on effects of a heat exchanger on broiler performance, energy use, and calculated carbon dioxide emission at commercial broiler farms, and the experiences of farmers using a heat exchanger. Poultry Sci. 89:27432750. http://dx.doi.org/10.3382/ps.2010-00902

Dagtekin, M, C. Karaca, \& Y. Yilzid. 2009. Performance, Characteristics of a pad evaporative cooling system in a broiler house in a Mediterranean climate. J. Biosyst Eng. 103: 100104. http://dx.doi.org/10.1016/j.biosystemseng.2009.02.011

Donald, J. O. 2010. Environmental Manajemen in the Broiler House. www.aviagen.com. [Februari 9, 2014].

Dozier, W. A., J. L. Purswell, \& S. L. Branton. 2006. Growth responses of male broilers subjected to high air velocity for either twelve or twenty-four hours from thirty-seven to fifty-one days of age. J. Appl. Poult. Res. 15:362-366. http:// dx.doi.org/10.1093/japr/15.3.362

Herawati \& G. Adiwinarto. 2012. Effective temperature at finisher phase to promote relative growth rate of broiler strain cob. Int. J. Poult. Sci. 11: 644-648. http://dx.doi.org/10.3923/ ijps.2012.644.648

Lam, C. K. G, K. A. Bremhorst. 1981. Modified form of model for predicting wall turbulence. ASME Journal of Fluids Engineering. 103: 456-460

Lee, I. B., S. Sase, \& S. H. Sung. 2007. Evaluation of CFD acuuracy for ventilation study of a naturally ventilated broiler house. JARQ. 41: 53-64. http://dx.doi.org/10.6090/ jarq. 41.53

Pereira, D. F. \& I. A.Naas. 2008. Estimating the thermoneutral zone for broiler breeders using behavioral analysis. J. Comput Electron Agr. 62:2-7. http://dx.doi.org/10.1016/ j.compag.2007.09.001 
Seoa, I. H., I. B. Leea, O. K. Moonb, H. T. Kimc, H. S. Hwanga, S. W. Honga, J. P. Bitoga, J. I.Yooa, K. S.Kwona, Y. H. Kima, \& J. W. Hanc. 2009. Improvement of the ventilation sistem of a naturally ventilated broiler house in the cold season using computational simulations. J. Biosyst Eng. 104: 106 - 117. http://dx.doi.org/10.1016/j.biosystemseng.2 009.05.007

Versteeg, H. K. \& W. Malalasekera. 1995. An Introduction to Computational Fluid Dynamic The Finite Volume Method. Longman Scientific and Thechnical, Harlow.

Vidal, V. B., E. Guijarro, S. Balasch, \& A. G. Torres. 2008. Application of computational fluid dynamics to the prediction of airflow in a mechanically ventilated commercial poultry building. J. Biosyst Eng. 100:105-116. http://dx.doi. org/10.1016/j.biosystemseng.2008.02.004
Yahav, S., A. Straschnow, D. Luger, D. Shinder, J. Tanny, \& S. Cohen. 2004. Ventilation, sensible heat loss, broiler energy, and water balance under harsh environmental conditions. Poultry Sci. 83: 253-258. http://dx.doi.org/10.1093/ ps/83.2.253

Yani, A. \& B. P. Purwanto. 2006. Pengaruh iklim mikro terhadap respons fisiologis sapi perah peranakan Fries Holland dan modifikasi lingkungan untuk meningkatkan produktivitasnya (ULASAN). Med. Pet. 29: 35-46.

Yani, A., H. Suhardiyanto, R. Hasbullah, \& B. P. Purwanto. 2007. Analisis dan simulasi distribusi suhu udara pada kandang sapi perah menggunakan Computational Fluid Dynamics (CFD). Med.Pet. 30: 218-228. 